\title{
PENGEMBANGAN INSTRUMEN LITERASI HUMANISTIK DAN KEMAMPUAN PEMECAHAN MASALAH PADA PEMBELAJARAN IPA KELAS V SD
}

\author{
I.M.A.A. Putra ${ }^{1}$, I.W. Lasmawan ${ }^{2}$, N.K. Suarni ${ }^{3}$ \\ ${ }^{123}$ Program Studi Pendidikan Dasar \\ Universitas Pendidikan Ganesha \\ Denpasar, Indonesia \\ e-mail: agus.astina@undiksha.ac.id ${ }^{1}, \frac{\text { wayan.lasmawan@undiksha.ac.id }}{2}$,
}

\begin{abstract}
Abstrak
Penelitian ini bertujuan untuk mengetahui dan mendeskripsikan validitas isi dan reliabilitas instrumen kemampuan literasi humanistik dan kemampuan pemecahan masalah pada pembelajaran IPA kelas V SD. Penelitian ini merupakan penelitian pengembangan dengan desain penelitian 4D. Subyek penelitian ini meliputi 2 dosen ahli dan 3 praktisi (guru). Metode pengumpulan data menggunakan angket. Metode analisis data dalam penelitian ini menggunakan uji validitas is (lawshe) dan uji reliabilitas (alpha Cronbach). Hasil penelitian: 1) hasil uji validitas instrumen kemampuan literasi humanistik yang dikembangkan mendapatkan hasil $C V I=0,68$ dengan katagori validitas tinggi. 2) uji validitas instrumen kemampuan pemecahan masalah yang di kembangkan mendapatkan hasil $\mathrm{CVI}=0,84$ dengan kriteria validitas tinggi. 3) hasil uji reliabilitas instrumen kemampuan literasi humanistik sebesar $\mathrm{r} 11=0,614$ dengan kriteria reliabilitas tinggi. 4) hasil uji reliabilitas instrumen kemampuan pemecahan masalah mendapatkan hasil sebesar $\mathrm{r} 11=0,614$ dengan kriteria reliabilitas tinggi.
\end{abstract}

Kata Kunci : Literasi Humanistik; Pembelajaran IPA; Pemecahan Masalah

\begin{abstract}
This study aims to determine and describe the validity of the content and reliability of the instrument of humanistic literacy abilities and problem solving abilities in the learning of science class V SD. This research is a development study with 4D research design. The subjects of this study include 2 expert lecturers and 3 practitioners (teachers). The data collection method uses a questionnaire. The method of data analysis in this study uses the validity test (lawshe) and the reliability test (Cronbach alpha). The results of the study: 1 ) the results of the test of the validity of the developed humanistic literacy ability instruments obtained $\mathrm{CVI}=0.68$ with a high validity category. 2) the test of the validity of the instrument developed problem solving ability to get the results of $\mathrm{CVI}=$ 0.84 with high validity criteria. 3) the reliability test results of the instrument of humanistic literacy ability of $\mathrm{r} 11=0.614$ with high reliability criteria. 4 ) the reliability test results of the instrument of problem solving ability get a result of $\mathrm{r} 11=0.614$ with high reliability criteria.
\end{abstract}

Keywords : Humanistic Literacy; Learning Science; Problem Solving

\section{PENDAHULUAN}

Perkembangan ilmu pengetahuan dan teknologi merupakan tantangan terbesar bagi manusian dalam kehidupannya. Tanpa adanya penerapan, pengembangan dan penguasaan teknologi, pembangunan nasional tidak akan berjalan sesuai dengan laju perkembangan negara-negara lainnya.
Penerapan, pengembangan dan penguasaaan teknologi tidak mungkin dapat dicapai dengan baik tanpa didukung dengan budaya kreatif dan inovasi dari sebagian besar masyarakat.

Revolusi industry 4.0 perlu mengembangkan literasi baru. Literasi baru mencangkup literasi data, literasi teknologi, dan literasi manusia. Literasi 
data terkait dengan kemampuan membaca, menganalisis dan membuat konklusi berpikir berdasarkan data dan imformasi, literasi teknologi berkaitan dengan kemampuan memahami cara kerja mesin dan literasi manusia terkait dengan kemampuan komunikasi, kolaborasi, berpikir kritis, kreatif dan inovatif (Sanjayanti, 2018). Disamping memiliki kemampuan literasi humanistik pada era revolusi industry 4.0 siswa juga harus memiliki kompetensi unggul dengan berbagai kemampuan, salah satunya kemampuan pemecahan masalah. Hal tersebut dapat tercapai melalui pendidikan khususnya pada pendidikan formal.

Pendidikan sekolah dasar merupakan jenjang pendidikan formal pertama dalam pendidikan di Indonesia. Pendidikan di sekolah dasar merupakan pondasi pengetahuan awal untuk melanjutkan kejenjang pendidikan yang lebih tinggi. Dikemukakan pada pasal Pasal 1 Peraturan Pemerintah Republik Indonesia Nomor 32 Tahun 2013 Tentang Perubahan atas Peraturan Pemerintah Nomor 19 Tahun 2005 Tentang Standar Nasional yang mengemukakan bahwa untuk mencapai tujuan pendidikan perlu menggunakan kurikulum sebagai sebuah pedoman. Upaya tersebut dilakukan dari tingkat pusat sampai dengan sekolah terutamanya guru sebagai ujung tombak pelaksanaan kegiatan pembelajaran di kelas. Perubahan kurikulum telah dilakukan beberapa kali, yang terbaru diterapkan kurikulum 2013. Salah satu muatan pelajaran yang terkadung dalam kurikulum K13 di sekolah dasar adalah pembelajaran IPA.

Pembelajaran IPA merupakan serangkaian kegiatan yang melibatkan guru, siswa, dan bahan ajar IPA dalam rangka mencapai perubahan yang relatif tetap dalam pengetahuan, pemahaman, sikap, tingkah laku, dan keterampilan. Proses pembelajaran IPA di SD, diharapkan seorang guru mampu menciptakan suasana belajar yang menyenangkan, aktif dan bervariasi, agar dapat mengoptimalkan kegiatan belajar siswa dan mampu memberikan penilaian yang efektif untuk siswa, baik dari segi penetahuan siswa, sikap siswa dan keterampilan siswa sehingga penilaian yang dilakukan oleh guru tepat sasaran sesuai dengan kondisi dan pengetahuan yang dimiliki oleh anak. Maka dari itu, diperlukan pembaharuan dalam proses penilaian di kelas yang lebih mengacu kepada proses, keterampilan, sikap dan pengetahuan siswa, sehingga menyebabkan penilaian yang dilakukan oleh guru terhadap kemampuan siswa menjadi efektif, sehingga penilaian yang dilakukan oleh guru menjadi akurat dan tepat sasaran.

Maka dari itu, pembelajaran maupun penilaian yang di lakukan oleh guru hendaknya dapat memotivasi anak untuk belajar dan mengarahkan anak untuk mengembangkan kemampuan yang dimiliki oleh anak tersebut. Untuk mencapai keberhasilan dalam mengembangkan pengetahuan, sikap dan keterampilan anak maka proses pembelajaran harus dirancang dengan matang oleh guru, baik dalam penyusunan bahan ajar, proses pembelajaran serta penilaian yang tepat sasaran sesuai dengan kebutuhan dan perkembangan anak.

Berdasarkan observasi yang dilakukan pada tanggal 25 November 2019 di SD Gugus X Kecamatan Kintamani tampak bahwa penilaian yang digunakan oleh guru masih menggunakan penilaian lama yang hanya menilai dari segi pengetahuan anak saja, dan penilain tersebut didapat melalui nilai ulangan harian dan ulangan umum tanpa menilai dari segi keaftifan siswa, dari segi proses yang sudah dilakukan oleh siswa, dan dari segi sikap serta keterapilan anak atau dapat dikatakan bahwa penilaian yang dilakukan oleh guru bersifat kovensional dengan ranah kognitif yang masih tergolong rendah. Penilaian tersebut menurut peneliti kurang efektif digunakan karena hanya menilai siswa dari segi kognitif tanpa melihat dari segi keterampilan dan sikap siswa dalam memecahkan masalah yang diberikan oleh guru pada saat proses belajar mengajar berlangsung.

Oleh karena itu diperlukan suatu pembaharuan atau pengembangan istrument yang dapat menilai siswa dari 
segi keterampilan, sikap dan pengetahuan siswa sehinga penilaian yang di lakukan oleh guru menjadi efektif dan tepat sasaran. Maka dari itu peneliti akan mengembangkan intrumen untuk menilai kemampuan literasi humanistic dan kemampuan pemecahan masalah pada pembelajaran IPA di sekolah dasar.

Literasi Humanistik, menurut UNESCO (dalam Sanjayanti, 2018 ) menjelaskan bahwa kemampuan literasi merupakan hak setiap orang dan merupakan dasar untuk belajar sepanjang hayat. Kemampuan literasi dapat memberdayakan dan meningkatkan kualitas individu, keluarga, masyarakat. Karena sifatnya yang "multiple Effect" atau dapat memberikan efek untuk ranah yang sangat luas, kemampuan literasi membantu memberantas kemiskinan, mengurangi angka kematian anak, pertumbuhan penduduk, dan menjamin pembangunan berkelanjutan, dan terwujudnya perdamaian. Buta huruf, bagaimanapun, adalah hambatan untuk kualitas hidup yang lebih baik.

Penilaian kemampuan literasi humanistik ini akan diguanakan untuk menilai kemampuan yang dimiliki oleh anak sehingga anak bisa berfungsi baik di lingkungannya dan dapat memahami interaksi dengan anak yang lainnya dan guru (Sanjayanti, 2018). Literasi manusia/ literasi humanistik yang digagas pemerintah menekankan penguatan SDM yang memiliki keunggulan komunikasi dan desain atau rancangan (Hamidulloh lbda, 2018). Penilaian kemampuan literasi humanistiik ini akan menilai terkait dengan kemampuan komunikasi, kolaborasi, berpikir kritis, kreatif dan inovatif (Rozak dalam Sanjayanti, 2018)

Carl I. Hovland (dalam Sanjayanti, 2018) mengatakan bahwa komunikasi adalah proses dimana seseorang (komunikator) menyampaikan perangsang (biasanya lambing lambang dalam bentuk kata-kata) untuk merubah tingkah laku orang-orang lain (komunikan). Sedangkan Everett M. Rogers (dalam Sanjayanti, 2018) seorang pakar Sosiologi Pedesaan Amerika memdefinisikan komunikasi sebagai proses dimana suatu ide dialihkan dari sumber kepada satu penerima atau lebih, dengan maksud untuk mengubah tingkah laku mereka.

Menurut Abdulsyani (dalam

Sanjayanti, 2018), menyatakan bahwa kolaborasi adalah suatu bentuk proses sosial, dimana didalamnya terdapat aktivitas tertentu yang ditujukan untuk mencapai tujuan bersama dengan saling membantu dan saling memahami aktivitas masing-masing. Sedangkan Menurut Ted Panitz (dalam Suryani, 2010) kolaborasi adalah filsafat interaksi dan gaya hidup yang menjadikan kerjasama sebagai suatu struktur interaksi yang dirancang sedemikian rupa guna memudahkan usaha kolektif untuk mencapai tujuan bersama. Pada segala situasi, ketika sejumlah orang berada dalam suatu kelompok, kolaborasi merupakan suatu cara untuk berhubungan dengan saling menghormati dan menghargai kemampuan dan sumbangan setiap anggota kelompok.

Berpikir kritis adalah pengambilan keputusan yang penuh pertimbangan dan dilakukan secara mandiri. Peter Facione, (dalam Sanjayanti, 2018) mengemukakan bahwa berpikir kritis merupakanp Proses perumusan alasan dan pertimbangan mengenai fakta, keadaan, konsep, metode dan kriteria. Richard Paul (dalam Sanjayanti, 2018) mendefinisikan berpikir kritis sebagai proses merumuskan alasan yang tertib secara aktif dan terampil dari menyusun konsep, mengaplikasikan, menganalisis, mengintegrasikan (sintesis), atau mengevaluasi informasi yang dikumpulkan melalui proses pengamatan, pengalaman, refleksi, pemberian alasan (reasoning) atau komunikasi sebagai dasar dalam menentukan tindakan.

Kreativitas Menurut John Adair (dalam Sanjayanti, 2018) adalah daya pikir dan semangat yang memungkinkan kita untuk mengadakan sesuatu yang memiliki kegunaan, tatanan, keindahan, atau arti penting dari sesuatu yang kelihatannya tidak ada. Sedangkan Inovatif yaitu Usaha seseorang dengan mendayagunakan pemikiran, kemampuan imajinasi, berbagai stimulan, dan individu yang mengelilinginya dalam menghasilkan produk baru, baik bagi dirinya sendiri ataupun lingkungannya (Sanjayanti, 2018) 
Pemecahan masalah umumnya dianggap sebagai aktivitas kognitif yang paling penting dalam konteks sehari-hari dan professional. Namun, belajar untuk memecahkan masalah diperlukan pengaturan tingkatan pendidikan formal karena pemahaman tentang proses yang terbatas (Jonassen dalam Nayazik, 2017). Tujuan pemecahan masalah ialah memperoleh kemampuan dan kecakapan kognitif untuk memecahkan masalah secara rasional, lugas, dan tuntas (Febrianti, 2017).

$$
\text { Menurut John Dewey (dalam }
$$

Prahani, 2016) pemecahan masalah adalah proses yang disengaja yang terdiri dari langkah-langkah berikut: : (1) Mengenali/menyajikan masalah: tidak diperlukan strategi pemecahan masalah jika bukan merupakan masalah; (2) Mendefinisikan masalah: strategi pemecahan masalah menekankan pentingnya definisi masalah guna menentukan banyaknya kemungkinan penyelesaian; (3) Mengembangkan beberapa hipotesis: hipotesis adalah alternatif penyelesaian dari pemecahan masalah, (4) Menguji beberapa hipotesis: mengevaluasi kelemahan dan kelebihan hipotesis, (5) Memilih hipotesis yang terbaik.

Sejalan dengan hal tersebut Krulik dan Rudnik (dalam Muiz Lidinillah, 2008) mengenalkan lima tahapan pemecahan masalah yang mereka sebut sebagai heuristik. mereka mengkhususkan langkah ini dapat diajarkan di sekolah dasar. Lima langkah tersebut adalah: (1) Read and Think (Membaca dan Berpikir), yang meliputi kegiatan mengidentifikasi fakta, mengidentifikasi pertanyaan, memvisualisasikan situasi, menjelaskan setting, dan menentukan tindakan selanjutya. (2) Explore and Plan (Ekplorasi dan Merencanakan), yang meliputi kegiatan: mengorganisasikan informasi, mencari apakah ada informasi yang sesuai/diperlukan, mencari apakah ada informasi yang tidak diperlukan, mengambar/mengilustrasikan model masalah, dan membuat diagram, tabel, atau gambar. (3) Select a Strategy (Memilih Strategi), yang meliputi kegiatan : menemukan/membuat pola, bekerja mundur, coba dan kerjakan, simulasi atau eksperimen, Penyederhanaan atau ekspansi, membuat daftar berurutan, deduksi logis, dan membagi atau mengkategorikan permasalahan menjadi masalah sederhana. (4) Find an Answer (Mencari Jawaban), yang meliputi kegiatan: memprediksi, menggunakan kemampuan berhitung, menggunakan kemampuan aljabar, menggunakan kemampuan geometris, dan menggunakan kalkulator jika diperlukan. (5) Reflect and Extend (Refleksi dan Mengembangkan), memeriksa kembali jawaban, menentukan solusi alternatif, mengembangkan jawaban pada situasi lain, mengembangkan jawaban (generalisasi atau konseptualisasi), mendiskusikan jawaban, dan menciptakan variasi masalah dari masalah awal.

Untuk penilaian pemecahan masalah yang dikembangkan oleh peneliti untuk dapat digunakan pada saat proses pembelajaran di kelas khususnya pada muatan Pembelajaran IPA. Kemampuan pemecahan masalah dapat dilatih untuk peserta didik di mana peserta didik membangun pengetahuan melalui bekerja sama dalam lingkungan sosial untuk belajar dan memecahkan masalah atau menghasilkan produk (Burns et al., DeWitt et al., Laal \& Ghodsi, dalam Fararoti Alfin dkk, 2019). Penilain kemampuan pemecahan masalah ini berkaitan pada penilaian proses identifikasi individu terhadap situasi masalah, penjelasan jawaban sementara atau hipotesis, pengujian hipotesis melalui pengambilan data dan evaluasi data, dan menyampaikan hipotesis atau menarik kesimpulan pada suatu masalah (Skell dalam Febrianti, 2017).

Tujuan dari diadakan penelitian ini yaitu: 1) untuk mengetahui dan mendeskripsikan validitas instrumen kemampuan literasi humanistik pada pembelajaran IPA kelas V SD, 2) untuk mengetahui dan mendeskripsikan validitas instrumen kemampuan pemecahan masalah pada pembelajaran ipa IPA kelas $V$ SD, 3) untuk mengetahui dan mendeskripsikan reliabilitas instrumen kemampuan literasi humanistik pada pembelajaran IPA kelas V SD, dan 4) 
untuk mengetahui dan mendeskripsikan reliabilitas instrumen kemampuan pemecahan masalah pada pembelajaran IPA kelas V SD.

\section{METODE}

Penelitian ini menggunakan model penelitian dan pengembangan pendidikan (educational research and development) yang bertujuan untuk mengembangkan intrumen kemampuan berpikir kritis dan literasi humanistic pada pembelajaran IPA kelas $V$ SD. Desain penelitian ini menggunakan model pengembangan 4D (four-D). Menurut Thiagarajan et al (dalam Trianto,2012) model menelitian dan pengembangan model 4D terdiri dari 4 tahapan, yaitu; define, design, develop, dan disseminate atau dapat diadaptasi menjadi 4P, yaitu; pendefinisian, perancangan, pengembangan, dan penyebaran. Subyek pada penelitian pengembangan seperti ini dapat meliputi para ahli dan praktisi, dalam hal ini adalah 2 dosen Pendidikan Dasar dan 3 guru kelas V Sekolah Dasar. Dalam penelitian ini, ada dua variabel yang digunakan yaitu intrumen kemampuan berpikir kritis dan intrumen literasi humanistik pada pembelajaran IPA kelas V SD. Variabel dapat diartikan sebagai suatu totalitas gejala atau objek pengamatan yang akan diteliti (Dantes 2012). Prosedur penelitian dalam pengembangan produk instrument kemampuan berpikir kritis dan literasi humanistik kelas V SD adalah sebagai berikut : (a) define / Analisis kebutuhan dilakukan melalui studi literatur dan studi lapangan/ empirik. Studi literatur dilakukan untuk mengkaji standar isi kurikulum 2013.

Adapun kegiatan yang dilakukan pada studi literatur sebagai berikut : Menganalisis standar isi (kompetensi inti dan kompetensi dasar) untuk membuat jaring tema, jaring sub tema sehingga menghasilkan intrumen kemampuan berpikir kritis dan literasi humanistik, Menyususn indikator dan dan ranah kognitif, dan studi lapangan/ empirik dilakukan dengan mengobservasi aktivitas guru dan siswa dalam pelaksanaan pembelajaran di sekolah dasar sesuai dengan kurikulum 2013. (b) Pada tahap perancangan (design) hasil-hasil yang diperoleh dari studi literatur dan studi lapangan digunakan untuk merancang intrumen kemampuan berpikir kritis dan literasi humanistik. Pada rancangan draf Intrumen ini kegiatan yang dilakukan adalah menganalisis kurikulum, pemetaan jejaring tema kelas $\mathrm{V}$ untuk mengembangkan prototype intrumen, yang nantinya akan divalidasi oleh ahli dan validasi oleh praktisi untuk mengetahui kelemahan-kelemahan konstruks instrument kemampuan berpikir kritis dan literasi humanistik yang telah dikembangkan dan sesuai dengan masukan yang diberikan, maka dilakukan penyempurnaan untuk mendapatkan draf instrument kemampuan berpikir kritis dan literasi humanistik yaitu : Pengembangan intrumen sesuai dengan validasi ahli, Validitas ahli dilakukan untuk memastikan pengembangan instrument kemampuan berpikir kritis dan literasi humanistik sesuai dengan isi, Validasi produk instrumen oleh praktisi guru senior (ahli kurikulum), dan Revisi produk (Intrumen), (c) Tahap pengembangan (develop) produk akhir dari penelitian dan pengembangan ini adalah instrument kemampuan berpikir kritis dan hasil belajar IPA yang valid, reliabel dan relevan untuk diterapkan dalam pembelajaran (validasi skup terbatas). Hasil pengujian kemudian digunakan untuk revisi sehingga produk memenuhi kriteria kelayakan (secara teoretik) untuk diimplementasi, (d) Thiagarajan (1974: 9) membagi tahap disseminate dalam tiga kegiatan yaitu: validation testing, packaging, diffusion and adoption. Pada tahap validation testing, produk yang sudah direvisi pada tahap pengembangan kemudian diimplementasikan pada sasaran yang sesungguhnya.

Pada penelitian pengembangan ini teknik pengumpulan data dapat menggunakan tes essay dan teknik kuesioner atau angket. Tes dan kuesioner digunakan untuk mengukur kelayakan/ validasi dari produk telah dikembangkan. Dalam penelitian ini validitas yang diuji yaitu instrumen kemampuan berpikir kritis dan literasi humanistik diuji terlebih validasi oleh 3 praktisi dari guru SD dan 2 Pakar Dosen Pendas. Instrumen disebut 
valid apabila benar-benar mampu mengukur apa yang semestinya diukur dengan instrumen tersebut (Candiasa, 2010:21). Hasil validasi dari validator dianalisis menggunakan analisis Content Validity Ratio (CVR)

Ketentuan tentang indeks CVR menurut Lawshe (1975) sebagai berikut: (a) Saat jumlah responden yang menyatakan setuju atau sangat setuju kurang dari $1 / 2$ total responden maka nilai CVR = - , (b) Saat jumlah responden yang menyatakan setuju atau sangat setuju $1 / 2$ dari total responden maka nilai $\mathrm{CVR}=0$, (c) Saat seluruh responden menyatakan setuju atau sangat setuju maka nilai CVR $=1$ (hal ini diatur menjadi 0,99 disesuaikan dengan jumlah). Karena jumlah responden yang digunakan dalam penelitian ini ada 5 orang maka nilai kritis CVR $=0,99$, (d) Saat jumlah responden yang menyatakan setuju atau sangat setuju lebih dari $1 / 2$ total responden maka nilai $C V R=0-0,99$. Setelah mengidentifikasi setiap sub pertanyaan instrumen dengan menggunakan CVR, maka selanjutnya yaitu menghitung CVI (Content Validity Index). CVI digunakan untuk menghitung rata-rata dari keseluruhan nilai CVR untuk komponen instrumen kemampuan berpikir kritis dan literasi humanistik.

Dalam penelitian ini uji reliabilitas dilakukan dengan menggunakan teknik formula alpha cronbach. menurut arikunto (2009), rumus alpha cronbach digunakan untuk mencari reliabillitas instrument yang skornya bukan 1 dan 0 , seperti angket atau soal bentuk uraian. Rumus alpha cronbach sebagai berikut.

\section{HASIL DAN PEMBAHASAN}

Hasil

1) hasil uji validitas nstrumen kemampuan literasi humanistik pada pembelajaran IPA kelas V SD

Berdasarkan penggolongan validitas uji judges instrumen kemampuan literasi humanistik dengan 5 pakar, selanjutnya dilakukan perhitungan validitas isi dengan menggunakan rumus Lawshe. Adapun table kerja untuk menghitung validitas isi instrument kemampuan literasi humanistik dengan 5 pakar dipaparkan pada tabel 1 sebagai berikut

Tabel 1. Tabel Kerja Perhitungan Validitas Content Instrumen Kemampuan Berpikir Kritis dengan 5 Pakar

\begin{tabular}{ccccc}
\hline No. Butir & Relevan & Tidak relevan & CVR & Status Soal \\
\hline 1 & 5 & 0 & 1 & valid \\
2 & 4 & 1 & 0,6 & valid \\
3 & 4 & 1 & 06 & valid \\
4 & 5 & 0 & 1 & valid \\
5 & 4 & 1 & 0,6 & valid \\
6 & 4 & 1 & 0,6 & valid \\
7 & 5 & 0 & 1 & Valid \\
8 & 4 & 1 & 0,6 & Valid \\
9 & 4 & 1 & 0,6 & Valid \\
10 & 4 & 1 & 0,6 & Valid \\
& $\sum$ CVR & 7,2 & & \\
\hline
\end{tabular}

Berdasarkan table kerja perhitungan validitas isi kemampuan literasi humanistik dengan 5 pakar mendapatkan hasil bahwa semua butir rubrik pengamatan 
kemampuan lierasi humanistik yang di kembangkan dinyatakan valid. Hasil perhitungan content validity index instrument kemampuan literasi humanistik yang di kembangkan mendapatkan hasil sebesar $\mathrm{CVI}=0,72$. Hal ini berarti, instrument literasi humanistik yang di kembangkan termasuk ke dalam kriteria validitas tinggi.
2) Hasil uji validitas instrumen kemampuan pemecahan masalah pada pembelajaran IPA kelas $V$ SD

Berdasarkan penggolongan validitas uji judges instrumen kemampuan literasi humanistik dengan 5 pakar, selanjutnya dilakukan perhitungan validitas isi dengan menggunakan rumus Lawshe. Adapun table kerja untuk menghitung validitas isi instrument kemampuan literasi humanistik dengan 5 pakar dipaparkan pada tabel 2 sebagai berikut.

Tabel 2. Tabel Kerja Perhitungan Validitas Isi Instrumen Kemampuan Literasi Humanistik dengan 5 Pakar

\begin{tabular}{ccccc}
\hline No. Butir & Relevan & Tidak Relevan & CVR & Status Soal \\
\hline 1 & 5 & 0 & 1 & Valid \\
2 & 4 & 1 & 0,6 & Valid \\
3 & 4 & 1 & 0,6 & Valid \\
4 & 4 & 1 & 0,6 & Valid \\
5 & 5 & 0 & 1 & Valid \\
6 & 5 & 0 & 1 & Valid \\
7 & 5 & 0 & 1 & Valid \\
8 & 5 & 0 & 1 & Valid \\
9 & 5 & 0 & 1 & Valid \\
10 & 5 & 0 & 1 & Valid \\
11 & 5 & 0 & 1 & Valid \\
12 & 4 & 1 & 0,6 & Valid \\
& LVR & & 10,4 &
\end{tabular}

Berdasarkan table kerja perhitungan validitas isi kemampuan pemecahan masalah mendapatkan hasil bahwa semua butir rubrik pengamatan kemampuan pemecahan masalah yang di kembangkan dinyatakan valid. Hasil perhitungan content validity index instrument kemampuan pemecahan masalah yang di kembangkan mendapatkan hasil sebesar $\mathrm{CVI}=0,88$ dengan kriteria validitas tinggi.

3) Hasil Uji Reliabilitas Instrumen Kemampuan Literasi Humanistiik pada Pembelajaran IPA Kelas V SD
Uji reliabilitas instrumen kemampuan literasi humanistik pada pembelajaran IPA kelas V SD diuji oleh 5 pakar yaitu 2 ahli dan 3 praktisi (guru). Dalam hal ini semua butir item rubrik penilaian kemampuan literasi humanistik dinyatakan valid, maka dari itu semua item rubrik penilain kemapuan liiterasi humanistik dapat di uji reliabilitasnya. Table kerja untuk menghitung reliabilitas instrument literasi humannistik dengan 5 pakar menggunakan rumus alpha cronbach dapat dilihat pada tabel 3 sebagai berikut. 
Tabel 3. Tabel kerja untuk menghitung Reliabilitas Instrumen Kemampuan Literasi Humanistik dengan 5 pakar

\begin{tabular}{ccccccc}
\hline No & \multicolumn{7}{c}{ Pakar (Judges) } & IV & Total Skor \\
\hline 1 & 5 & 5 & 5 & 5 & 5 & 25 \\
2 & 3 & 4 & 4 & 3 & 4 & 18 \\
3 & 4 & 3 & 3 & 4 & 5 & 19 \\
4 & 5 & 4 & 5 & 5 & 5 & 24 \\
5 & 4 & 3 & 4 & 3 & 5 & \\
6 & 5 & 5 & 3 & 4 & 3 & 20 \\
7 & 5 & 4 & 5 & 5 & 5 & 24 \\
8 & 5 & 5 & 5 & 5 & 5 & 25 \\
9 & 4 & 5 & 3 & 4 & 3 & 19 \\
10 & 4 & 3 & 5 & 5 & 5 & 215 \\
$\sum \mathrm{X}$ & 44 & 41 & 42 & 43 & 45 & 21.5 \\
$\mathrm{M}$ & 4,4 & 4,1 & 4,2 & 4,3 & 4,5 & 7,05 \\
$\sigma \frac{2}{b}$ & 0.44 & 0.69 & 0.76 & 0.61 & 0.65 & \\
$\sum \sigma \frac{2}{b}$ & $0,44+0,69+0,76+0,61+0,65=3.15$ & & \\
$\sigma \frac{2}{t}$ & 7,05 & & & & & \\
\hline
\end{tabular}

Berdasarkan hasil uji reliabilitas instrumen kemampuan literasi humanistik dengan 5 pakar menggunakan rumus alpha cronbach mendapatkan hasil sebesar $r 11=0,614$. Hal ini berarti, instrument kemampuan literasi pada pembelajaran IPA kelas $\mathrm{V}$ Sd yang di kembangkan berada pada kriteria reliabilitas tinggi.
4) Hasil Uji Reliabilitas Instrument Pemecahan Masalah pada Pembelajaran IPA Kelas V SD

Uji reliabilitas instrumen kemampuan pemecahan masalah pada pembelajaran IPA kelas V SD diuji oleh 5 pakar yakni 2 ahli dan

Tabel 4. Table kerja untuk menghitung Reliabilitas Instrumen Kemampuan Literasi Humanistik dengan 5

\begin{tabular}{|c|c|c|c|c|c|c|}
\hline \multirow{2}{*}{ No } & \multicolumn{5}{|c|}{ Pakar (Judges) } & \multirow[b]{2}{*}{ Total Skor } \\
\hline & I & II & III & IV & $\mathrm{V}$ & \\
\hline 1 & 5 & 5 & 4 & 3 & 2 & 19 \\
\hline 2 & 4 & 4 & 3 & 4 & 3 & 18 \\
\hline 3 & 3 & 2 & 3 & 5 & 4 & 17 \\
\hline 4 & 3 & 4 & 4 & 5 & 4 & 20 \\
\hline 5 & 5 & 4 & 3 & 4 & 3 & 19 \\
\hline 6 & 5 & 5 & 5 & 5 & 5 & 25 \\
\hline 7 & 5 & 3 & 5 & 5 & 5 & 23 \\
\hline 8 & 5 & 4 & 5 & 5 & 5 & 24 \\
\hline 9 & 5 & 5 & 5 & 5 & 5 & 25 \\
\hline 10 & 5 & 5 & 4 & 5 & 5 & 24 \\
\hline$\sum X$ & 45 & 41 & 41 & 46 & 41 & 214 \\
\hline
\end{tabular}




\begin{tabular}{ccccccc}
\hline \multirow{2}{*}{ No } & \multicolumn{5}{c}{ Pakar (Judges) } & \\
& $\mathrm{I}$ & $\mathrm{II}$ & $\mathrm{III}$ & $\mathrm{IV}$ & $\mathrm{V}$ & Total Skor \\
\hline $\mathrm{M}$ & 4.5 & 4.1 & 4.1 & 4.6 & 4.1 & 21.4 \\
$\sigma \frac{2}{b}$ & 0.65 & 0.89 & 0.69 & 0.44 & 1,09 & 8,64 \\
& $00.65+$ & & & & & \\
& $0,89+$ & & & & & \\
$\Sigma \sigma \frac{2}{b}$ & 0,69 & $+0,44+$ & & & & \\
& $1,09=$ & & & & \\
$\sigma \frac{2}{t}$ & 3.76 & 8,64 & & & & \\
$\mathrm{r} 11$ & 0,627 & & & & \\
\hline
\end{tabular}

Berdasarkan hasil uji reliabilitas instrumen kemampuan pemecahan masalah dengan 5 pakar menggunakan rumus alpha cronbach mendapatkan hasil sebesar $r 11=0,627$. Hal ini berarti, instrument kemampuan pemecahan masalah pada pembelajaran IPA kelas $\mathrm{V}$ SD yang di kembangkan berada pada kriteria reliabilitas tinggi.

\section{Pembahasan}

1) Pembahasan hasil uji validitas instrumen kemampuan pemecahan masalah pada pembelajaran IPA kelas V SD

Jumlah butir rubrik kemampuan literasi yang dikembangakan berjumblah 10 butir. Indikator yang digunakan dalam pengembangan instrument kemampuan literasi humanistik yaitu, 1) komunikasi, 2) berpikir kritis, 3) kolaboratif, dan 4) kreatif dan inovatif.

Berdasarkan hasil analiss uji validitas isi menggunakan rumus lawshe mendapatkan hasil bahwa seluruh butir rubrik instrument kemampuan litarsi humanistik dinyatakan valid dengan ratarata CVR sebesar 7,2. Setelah rata-rata CVR instrument kemampuan literasi didapat selanjutnya dilakukan perhitungan content valitidy index (CVI) mendapatkan hasil sebesar 0,72, hasil tersebut dikonversikan kedalam table kriteria validasi isi instrument kemampuan literasi humanistik berada pada kriteria validitas tinggi.

Menurut Fauziyah (2017) Hasil validasi perangkat pembelajaran digunakan untuk menentukan apakah perangkat pembelajaran dapat digunakan atau tidak. Validasi ahli dilakukan untuk mendapatkan saran perbaikan sekaligus merupakan penilaian para ahli terhadap rancangan pengembangan perangkat. Saran dari para ahli tersebut digunakan sebagai landasan penyempurnaan pengembangan perangkat yang telah disusun.

Berdasarkan hasil uji validitas isi intrumen tersebut dapat dikatakan bahwa (1) hasil penilaian oleh 5 pakar yang terdiri dari dua dosen ahli dan 3 praktisi (guru), instrumen rubrik penilaian yang akan dikembangkan bersifat layak untuk mengukur kemampuan literasi humanistik pada pembelajaran IPA kelas V SD, (2) berdasarkan penilaian validitas isi, keseluruhan butir rubrik pada instrumen kemampuan literasi humanistik bersifat valid, (3) berdasarkan hasil uji validitas keseluruhan butir rubrik penilaian bersifat valid Sehingga dari ketiga point diatas, instrumen rubrik penilaian yang telah dikembangkan dapat digunakan untuk mengukur kemampuan literasi humanistik siswa pada pemebalajaran IPA kelas $\mathrm{V}$ SD.

2) Pembahasan Hasil Uji Validitas Instrumen Kemampuan Pemecahan Masalah pada Pembelajaran IPA Kelas V SD

Indikator yang digunakan dalam pengembangan intrumen tes esay kemampuan pemecahan masalah yaitu, 1) Read and Think (Membaca dan Berpikir), 2) Explore and Plan (Ekplorasi dan 
Merencanakan), 3) Select a Strategy (Memilih Strategi), 4) Find an Answer (Mencari Jawaban) dan (5) Reflect and Extend (Refleksi dan Mengembangkan).

Berdasarkan hasil analiss uji validitas isi menggunakan rumus lawshe mendapatkan hasil bahwa seluruh butir tes esay instrument kemampuan pemecahan masalah dinyatakan valid tanpa revisi dengan rata-rata CVR sebesar 8,8. Setelah rata-rata CVR instrument kemampuan pemecahan masalah didapat selanjutnya dilakukan perhitungan content valitidy index (CVI) mendapatkan hasil sebesar 0,88. Hasil tersebut dikonversikan kedalam tabel kriteria validasi isi instrument kemampuan pemecahan masalah berada pada kriteria validitas sangat tinggi.

Hasil penelitian tersebut sejalan dengan penelitian yang dilakukan oleh Aditya Wardani pada tahun (2020) penelitian pengembangan instrumen tes keterampilan pemecahan masalah didapatkan hasil sebagai berikut yakni : (1) berdasarkan hasil penilaian oleh dua orang ahli, instrumen tes yang akan dikembangkan bersifat layak untuk mengukur keterampilan pemecahan masalah pada pokok bahasan listrik dinamis, (2) berdasarkan penilaian kesesuaian butir soal dengan inikator butir soal, keseluruhan butir soal pada instrumen tes bersifat valid, (3) berdasarkan hasil uji validitas dan uji reliabilitas keseluruhan soal bersifat valid dan reliabel.

Berdasarkan hasil uji validitas isi intrumen tes esay kemampuan pemecahan masalah pada pemebelajaran IPA kelas V SD tmendapatkan hasil bahwa: (1) hasil penilaian oleh 5 pakar yang terdiri dari dua dosen ahli dan 3 praktisi (guru), instrumen tes esay yang akan dikembangkan bersifat layak untuk mengukur kemampuan pemecahan masalah pada pembelajaran IPA kelas $\mathrm{V}$ SD, (2) berdasarkan penilaian validitas isi, keseluruhan butir rubrik pada instrumen kemampuan pemecahan masalah bersifat valid, (3) berdasarkan hasil uji validitas keseluruhan butir tes esay penilaian bersifat valid. Sehingga dari ketiga point diatas, instrumen tes esay yang telah dikembangkan dapat digunakan untuk mengukur kemampuan pemecahan masalah siswa pada pemebalajaran IPA kelas V SD.

3) Pembahasan Hasil Uji Reliabilitas Instrumen Kemampuan Literasi Humanistiik.

Uji reliabilitas instrumen kemampuan literasi humanistik pada pembelajaran IPA kelas V SD dilakukan setalah melakukan uji validitas isi terlebih ddahulu. Nilai-nilai untuk pengujian reliabilitas diambil dari skor-skor butir angket kemampuan literasi humanistik yang dinyatakan valid atau terpakai. Item yang tidak valid tidak dilibatkan dalam pengujian reliabilitas. Dalam hal ini semua butir item rubrik penilaian kemampuan literasi humanistik dinyatakan valid, maka dari itu semua item rubrik penilaian kemapuan literasi humanistik dapat di uji reliabilitasnya.

Berdasarkan bentuknya instrument kemampuan literasi humanistik yang di kembangkan berbentuk tes esai dengan teknik penskoran likert dengan skor 1 sampai 5. Berdasarkan hasil uji reliabilitas instrumen kemampuan literasi humanistik dengan 5 pakar menggunakan rumus alpha cronbach mendapatkan hasil sebesar $r 11=0,614$. Hal ini berarti, instrument kemampuan literasi pada pembelajaran IPA kelas $\mathrm{V}$ SD yang di kembangkan berada pada kriteria reliabilitas tinggi.

Berdasarkan hasil paparan tersebut, instrumen rubrik pengamatan yang dikembangkan mempunyai tingkat reliabilitas sebesar 0,614 dengan kriteria reliabilitas tinggi. Sehingga, instrumen rubrik pengamatan dapat digunakan untuk mengukur kemampuan literasi humanistik pada pembelajaran IPA kelas V SD.

4) Pembahasan Hasil Uji Reliabilitas Instrument Pemecahan Masalah pada Pembelajaran IPA Kelas V SD

Uji reliabilitas instrument kemampuan literasi humanistik diuji oleh 5 pakar yaitu 2 dosen ahli dan 3 praktisi dari guru. Instrument kemampuan literasi humanistik di uji reliabilitasnya menggunakan rumus formula alpha Cronbach. Menurut Arikunto (2009), rumus alpha cronbach digunakan untuk mencari reliabillitas instrument yang 
skornya bukan 1 dan 0 , seperti angket atau soal bentuk uraian.

Berdasarkan bentuknya instrument kemampuan literasi humanistik yang di kembangkan berbentuk tes esai dengan teknik penskoran likert dengan skor 1 sampai 5. Berdasarkan hasil uji reliabilitas instrumen kemampuan literasi humanistik dengan 5 pakar menggunakan rumus alpha cronbach mendapatkan hasil sebesar $r 11=0,614$. Hal ini berarti, instrument kemampuan literasi pada pembelajaran IPA kelas V SD yang di kembangkan berada pada kriteria reliabilitas tinggi.

Berdasarkan hasil paparan tersebut, instrumen rubrik pengamatan yang dikembangkan mempunyai tingkat reliabilitas sebesar 0,614 dengan kriteria reliabilitas tinggi. Sehingga, instrumen rubrik pengamatan dapat digunakan untuk mengukur kemampuan literasi humanistik pada pembelajaran IPA kelas V SD.

\section{PENUTUP}

Berdasarkan laporan hasil penelitian seperti yang telah dipaparkan pada bagian sebelumnya, maka dapat disimpulkan beberapa hasil penelitian sebagai berikut.

Pertama, hasil uji validitas isi pengembangan produk instrumen kemampuan literasi humanistik mendapatkan hasil sebesar CVI $=0,68$ dikatogorikan kedalam validitas tinggi.

Kedua, hasil uji validitas content pengembangan produk instrumen kemampuan pemecahan masalah mendapatkan hasil content validity index $\mathrm{CVI}=0,84$ dikatagorikan kedalam validitas sangat tinggi.

Ketiga, hasil uji reliabilitas instrumen kemampuan literasi humanistik mendapatkan hasil sebesar $r 11=0,614$. Hal ini berarti, instrument kemampuan literasi pada pembelajaran IPA kelas V SD yang di kembangkan berada pada kriteria reliabilitas tinggi.

Keempat, hasil uji reliabilitas instrumen kemampuan pemecahan masalah mendapatkan hasil sebesar $\mathrm{r} 11=$ 0,627. Hal ini berarti, instrument kemampuan pemecahan masalah pada pembelajaran IPA kelas $\mathrm{V} S \mathrm{~S}$ yang di kembangkan berada pada kriteria reliabilitas tinggi.

Adapun saran yang disampaikan dalam penelitian pengembangan instrumen kemampuan literasi humanistik dan kemampuan pemecahan masalah pada pembelajaran IPA kelas $\mathrm{V}$ SD sebagai berikut.

Pertama, Saran pemanfaatan untuk guru, disarankan untuk memanfaatkan instrumen asesmen literasi humanistik dan kemampuan pemecahan masalah pada pembelajaran IPA kelas V SD sebagai alat penilaian dalam proses pembelajaran kepada siswanya kushusnya pada muatan pembelajaran IPA dan memanfaatkan instrumen literasi humanistik dan kemampuan pemecahan masalah pada pembelajaran IPA kelas V SD.

Kedua saran desiminasi, disarankan untuk menyebarluaskan produk hasil pengembangan instrumen literasi humanistik dalam bentuk rubrik pengamatan dan instrument pemecahan masalah dalam bentuk tes esay muatan pembelajaran IPA di sekolah dasar dengan menyerahkan instrumen tersebut serta panduan penggunaan instrumen literasi humanistik dan instrumen kemampuan pemecahan masalah kepada guru di sekolah dasar serta menyebarluaskan melalui publikasi jurnal.

Ketiga saran pengembangan produk lebih lanjut, diharapkan bagi peneliti lain yang tertarik untuk melanjutkan penelitian ini, karena penelitian ini masih belum sempurna perlu penyebarluasan di sekolah dasar dan perlu dikembangkan lagi untuk penyempurnaan instrumen yang di kembangkan dalam penelitian ini.

\section{DAFTAR RUJUKAN}

Alfin, Fararoti dkk. 2019. Development of Group Science Learning (GSL) Model to Improve the Skills of Collaborative Problem Solving, Science Process, and SelfConfidence of Primary Schools Teacher Candidates. International Journal of Instruction Vol.12, No.1, January 2019.

Arikunto, Suharsimi. 2009. Dasar-dasar evaluasi pendidikan. Jakarta: PT Bumi Aksara. 
BSNP. 2006. Panduan Penyusuanan Kurikulum Tingkat Satuan Pendidikan Jenjang Pendidikan Dasar dan Menengah. Jakarta: Pusat Kurikulum.

Fauziyah, Laini. 2017. Model Problem Based Learning dengan Pendekatan Open Ended untuk Meningkatkan Kemampuan Pemecahan Masalah Siswa. Unnes Journal of Mathematics Education Research, Vol. 6, No. 1 tahun 2017, hal. 59-67

Febrianti, Pipit Eka \& Suprayitno. 2017. Penerapan Strategi Pembelajaran Everyone Is A Teacher Here Untuk Meningkatkan Keterampilan Pemecahan Masalah Sosial Siswa Pada Mata Pelajaran IPS Kelas IV Sdn Jatilangkung Mojokerto. Jurnal JPGSD, Volume 05 Nomer 03 ,Tahun 2017.

Ibda, Hamidulloh. 2018. Penguatan Literasi Baru Pada Guru Madrasah Ibtidaiyah Dalam Menjawab Tantangan Era Revolusi Industri 4.0. JRTIE: Journal of Research and Thought of Islamic Education. Vol. 1, No. 1, 2018.

Lidinillah, Dindin Abdul Muiz. 2008. Strategi Pembelajaran Pemecahan Masalah di Sekolah Dasar. http://file.upi.edu/Direktori/JURNAL/ PENDIDIKAN_DASAR/. Nomor 10 Oktober_2008

N.P.A.H., Sanjayanti. 2018. Diagnosa Literasi Humanistik Dalam Model Pembelajaran Konstruktivis pada Mahasiswa Politeknik Ganesha Guru. Seminar Nasional Riset Inovatif 2018, tersedia pada:. http://eproceeding.undiksha.ac.id/ind ex.php/senari/article/download/1548/ 984

Nayazik, Akhmad. 2017. Pembentukan Keterampilan Pemecahan Masalah melalui Model IDEAL Problem Solving dengan Teori Pemrosesan Informasi. Kreano, Jurnal Matematika Kreatif-Inovatif. Volume 8, Nomor 2 Tahun 2017 : 182-190.
Suryani, Nunuk. 2010. Implementasi Model Pembelajaran Kolaboratif Untuk Meningkatkan Ketrampilan Sosial Siswa. Jurnal majalah ilmiah pembelajaran. Vol. 8, No. 2, Oktober 2010

Susanto, Ahmad. 2013. Teori Belajar dan Pembelajaran Di Sekolah Dasar. Jakarta: Kencana Prenadamedia.

Thiagarajan, S., Semmel,d.S., \&semmel, M.I. (1974). Instructional development for training teachers of exeptional children. https://eric.ed.gov/?id=ED090725

Wardani, Aditya. 2020. Pengembangan Instrument Tes Keterampilan Pemecahan Masalah Pokok Bahasan Listrik Dinamis. Jurnal Kependidikan Betara (JKB), Vol. 1, No. 1, 2020, Hal. 14-19 